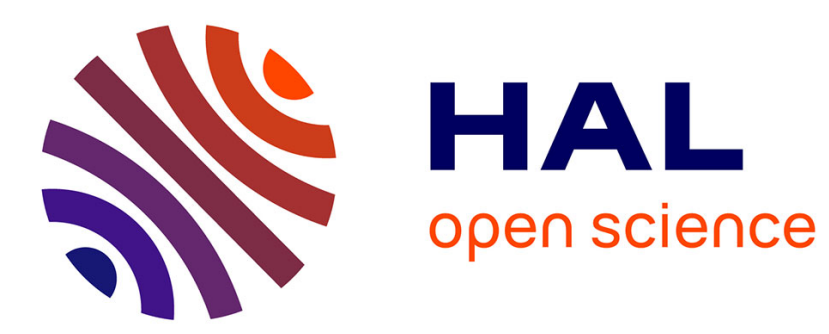

\title{
XRD and HREM Studies of Structural Phases in Non-Stoichiometric Complex Iron Oxides
}

W. Kaczmarek, M. Giersig

\section{To cite this version:}

W. Kaczmarek, M. Giersig. XRD and HREM Studies of Structural Phases in Non-Stoichiometric Complex Iron Oxides. Journal de Physique IV Proceedings, 1997, 07 (C1), pp.C1-83-C1-84. 10.1051/jp4:1997122 . jpa-00254892

\section{HAL Id: jpa-00254892 https://hal.science/jpa-00254892}

Submitted on 1 Jan 1997

HAL is a multi-disciplinary open access archive for the deposit and dissemination of scientific research documents, whether they are published or not. The documents may come from teaching and research institutions in France or abroad, or from public or private research centers.
L'archive ouverte pluridisciplinaire HAL, est destinée au dépôt et à la diffusion de documents scientifiques de niveau recherche, publiés ou non, émanant des établissements d'enseignement et de recherche français ou étrangers, des laboratoires publics ou privés. 


\title{
XRD and HREM Studies of Structural Phases in Non-Stoichiometric Complex Iron Oxides
}

\author{
W.A. Kaczmarek and M. Giersig*
}

\author{
Research School of Physical Sciences and Engineering, Australian National University, Canberra, A.C.T. \\ 0200, Australia \\ * Advanced Mineral Products Research Centre, University of Melborne, Parkville, VIC 3052, and \\ Hahn-Meitner-Institut, Abt. Kleinteilchenforschung, 14109 Berlin, Germany
}

\begin{abstract}
The influence of prolonged ball milling on structural changes of hexagonal and spinel type complex iron oxides has been studied by $x$-ray diffraction and high resolution electron microscopy. The XRD and HREM results for ball milled $\mathrm{SrFe}_{12} \mathrm{O}_{19}$ ferrite show fast decomposition and formation of $\mathrm{Fe}_{2} \mathrm{O}_{3}$ and $\mathrm{SrO}$ simple oxides. Microstructural developments for a powder mixture of $\mathrm{Co}(\mathrm{OH})_{2}$ and $\mathrm{Fe}_{2} \mathrm{O}_{3}$ show the formation of cubic type structure (spinel). By comparison with the XRD results, HREM analysis confirmed local phase separation, with magnetic $\mathrm{Fe}_{3} \mathrm{O}_{4}$ and $\mathrm{CoFe}_{2} \mathrm{O}_{4}$ nanosize (10-30 nm) particles being formed.
\end{abstract}

\section{INTRODUCTION}

The effects of prolonged milling on the magnetic properties and structural transformations in barium hexagonal as well as cobalt doped spinel ferrites have been described recently [1-2], (see also references therein). It was found for Ba ferrite, that during prolonged dry milling gas pressure has a major influence on structure, morphology and properties of the final powder particles [1]. Also it was postulated that chemical decomposition takes place through structural evolution in the sequence: crystalline (complex oxide) - amorphous - crystalline (simple oxides) [3]. The amorphous phase in this system under continuous milling (energy transfer to material) is unstable and only broadening of the x-ray diffraction (XRD) peaks has been observed. Furthermore, and most important by, the kinetics of the hexagonal $(\mathbf{B a}$ ferrite) to rhombohedral (hematite) structure transformation (i.e. complex ferrite decomposition) remain unexplained. More recently study of the hematite - magnetite transformation [4], has been extended to allow for the possibility of formation of multi-cation spinel structures by wet milling mixture of hematite and cobalt hydroxide in a oxygen free atmosphere [2]. The chemical reaction investigated : $\mathrm{Fe}_{2} \mathrm{O}_{3}+$ $\mathrm{Co}(\mathrm{OH})_{2} \Rightarrow \mathrm{CoFe}_{2} \mathrm{O}_{4}+\mathrm{H}_{2} \mathrm{O}$ for different $\mathrm{Fe}$-Co ratios and milling conditions showed formation of the new phase with the cubic structure (spinel type). XRD results showed that up to $\sim 14 \%$ at. of Co can be incorporated into a new cubic structure, however details of the stoichiometry of resultant nanocrystalline grains also remain unknown. In both cases further detailed microstructure analysis is required in order to better understand the transformations. In the present paper, we discuss some of the results from XRD analysis combined with high resolution electron microscopy (HREM) applied to ball-milled, structurally and chemically disordered $\mathrm{SrFe}_{12} \mathrm{O}_{19}$ and $\left(\mathrm{Co}_{0.133}\right.$ $-\mathrm{Fe}_{0.867)} \mathrm{O}_{4}$ ferrite. A HREM study was performed in order to understand the local structure of these materials.

\section{EXPERIMENTAL}

For the current study, all of the experimental investigations were performed on two ball milled ferrite samples. Commercially available strontium dodecairon nonadecoxide (Alfa-Johnson Matthey) was used as starting material for the first preparation with hematite (Koch-Light Labs. Ltd.) and cobalt(II) hydroxide (Aldrich) being used for the second preparation. Full details of the sample processing procedures and milling conditions have been presented recently [1-2]. The XRD experiments were carried out using a Philips diffractometer ( $\mathrm{CoK} \alpha$ radiation).
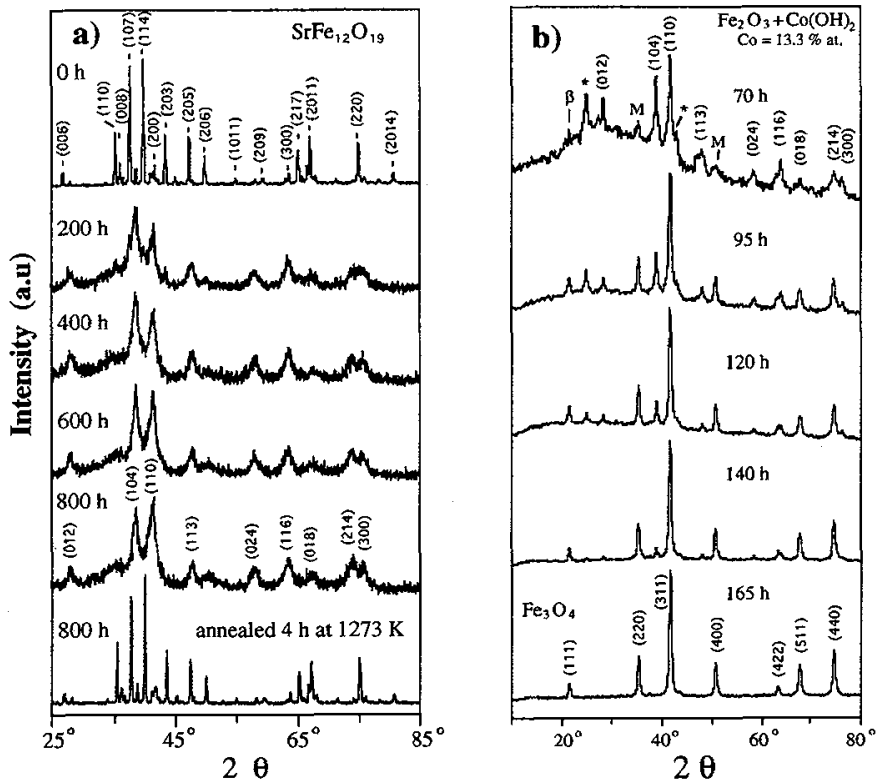

Fig.1. Evolution of XRD patterns vs milling time. Materials are described in text. 

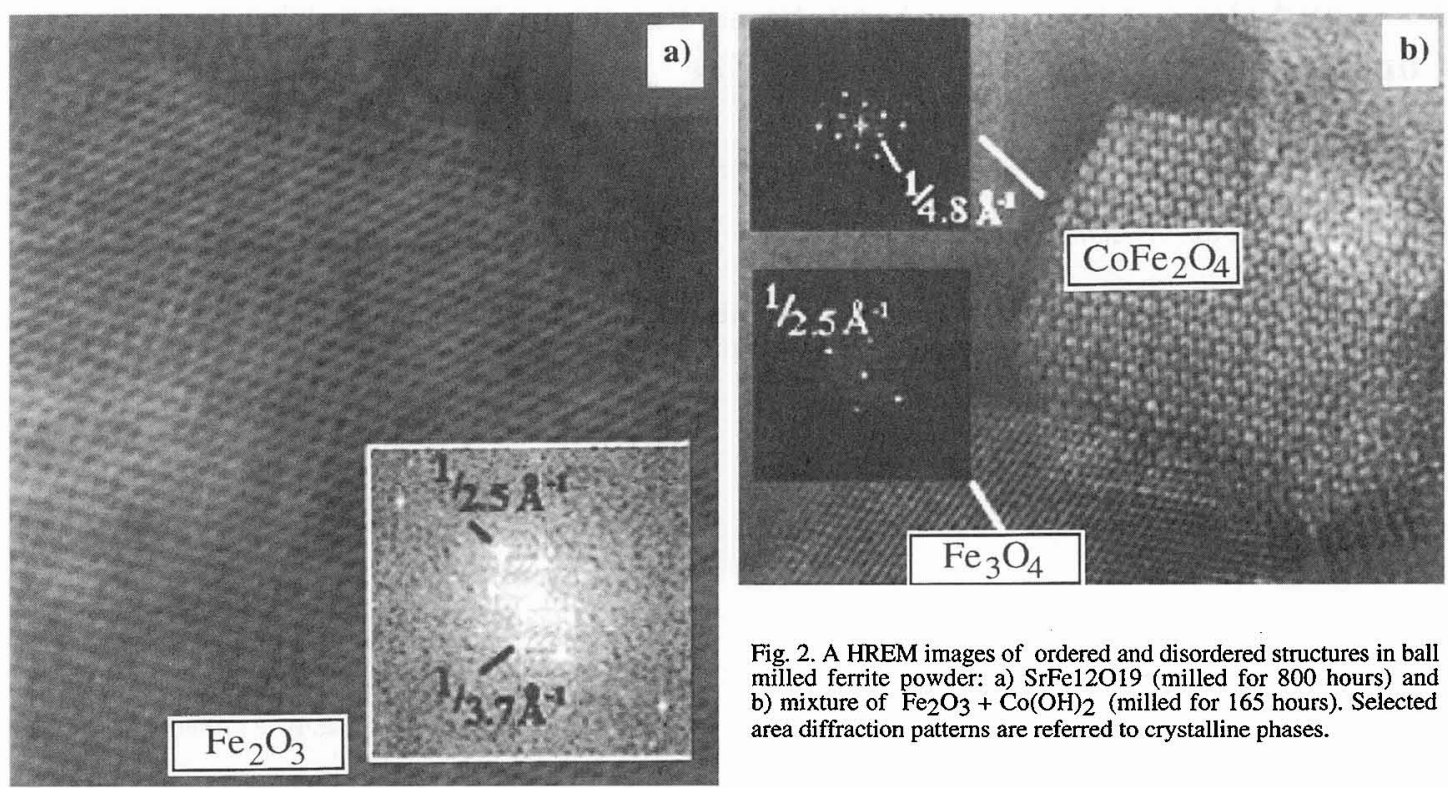

Fig. 2. A HREM images of ordered and disordered structures in ball milled ferrite powder: a) SrFe12019 (milled for 800 hours) and b) mixture of $\mathrm{Fe}_{2} \mathrm{O}_{3}+\mathrm{Co}(\mathrm{OH})_{2}$ (milled for 165 hours). Selected area diffraction patterns are referred to crystalline phases.

\section{RESULTS AND DISCUSSION}

The XRD patterns of the samples obtained on milling $\mathrm{SrFe}_{12} \mathrm{O}_{19}$ powder in vacuum for different periods of time are shown in Fig. 1 a. Several distinctive features can be observed on the ball-milled sample in comparison with the XRD pattern for the pre-milled powder $(0 \mathrm{~h})$. Firstly, commensurate with the significant peak broadening, the intensities of all of the diffraction peaks decrease with milling time. Indeed, for a sample milled for 200 hours the peaks of the Sr ferrite hexagonal structure practically disappear. Decomposition of $\mathrm{SrFe}_{12} \mathrm{O}_{19}$ to $\alpha-\mathrm{Fe}_{2} \mathrm{O}_{3}$ and $\mathrm{SrO}$ phases on ball-milling in vacuum is evident. This reflects the compositional make-up of strontium ferrite $\left(\mathrm{SrO} \cdot 6 \mathrm{Fe}_{2} \mathrm{O}_{3}\right)$ and the stable room temperature $\alpha-\mathrm{Fe}_{2} \mathrm{O}_{3}$ structure, which is resistant to wet or dry milling in air [6]. Comparing with the decomposition of $\mathrm{Ba}$ ferrite which occurs under the same milling conditions[1], the evolution of the XRD patterns presented here indicate that Sr ferrite is less stable structurally as the milling time required was found to be at least 5 times shorter. The question of the different structural stability for both hexagonal ferrites seems to be difficult to answer at the present stage. Another feature visible in the XRD patterns, with increasing milling time is the change of the peak intensity. In particular for the hematite structure, the two strongest lines ((104) and $(110)$ ) have a typical intensity ratio of $\sim 10: 7$ which is also characteristic for the $200 \mathrm{~h}$ milled sample. As the milling progresses, the value of $I_{(104)} / I_{(110)}$ ratio decreases. The same effect was found recently for dry hematite powder milled in a sealed container, for which the final product was found to be magnetite [7]. We assume that the Sr ferrite powder milled for 800 hours can be described as a multiphase mixture of $\alpha-\mathrm{Fe}_{2} \mathrm{O}_{3}, \mathrm{SrO}$ and $\mathrm{Fe}_{3} \mathrm{O}_{4}$. - a simple oxides which after $4 \mathrm{~h}$ annealing at $1273 \mathrm{~K}$ convert to $\mathrm{Sr}$ ferrite. The HREM image in Fig. 2 a shows a typical local microstructure, with fragments of $\sim 20 \mathrm{~nm}$ $\mathrm{Fe}_{2} \mathrm{O}_{3}$ particles being the main feature. The selected area diffraction pattern (SADP) shown as an insert, confirms rhombohedral (R-3c) type structure. In addition it was found that most of the iron oxide particles have a surrounding boundary of an amorphous nature. So far, expected from XRD $\mathrm{Fe}_{3} \mathrm{O}_{4}$ oxide phase and from the HREM the localisation and form (crystalline or amorphous) of $\mathrm{SrO}$ phase have been unconfirmed. For the second sample for the $\alpha-\mathrm{Fe}_{2} \mathrm{O}_{3}+\mathrm{Co}(\mathrm{OH})_{2}$ powders mixture wet milled in a $\mathrm{N}_{2}$ atmosphere, the following behaviour was observed. The evolution of the XRD patterns versus milling time presented in Fig. $1 \mathrm{~b}$, show evident for a structural phase transformation taking place during 165 hours of mechanical treatment. The XRD peaks attributed to the starting materials are still visible for the sample after $70 \mathrm{~h}$ of processing, with the lines from the $\alpha-\mathrm{Fe}_{2} \mathrm{O}_{3}$ structure marked by the Miller indices (hkl) and there from $\beta-\mathrm{Co}(\mathrm{OH})_{2}$ by $\beta$. Also additional XRD lines present in the pattern were assigned to goethite $\left(\mathrm{FeO}(\mathrm{OH})\right.$ ) and magnetite $\mathrm{Fe}_{3} \mathrm{O}_{4}$ and marked by * and $\mathrm{M}$ respectively. In the final powder only XRD lines characteristic of a cubic type structure were detected. These peaks are marked by the (hkl) indices of the $\mathrm{Fe}_{3} \mathrm{O}_{4}$ spinel structure. Results of XRD examination in this case are inconclusive due to the lack of information with regard to the Co localisation. In the present situation of the sample with Co 13.3 at. \% content in the starting powder mixture, formation of $\left(\mathrm{Co}_{0.133} \mathrm{Fe}_{0.867}\right)_{3} \mathrm{O}_{4}$ spinel ferrite would be expected on the basis of the XRD pattern. However, for the same sample the HREM image presented in Fig. $2 \mathrm{~b}$ shows more a complex microstructure with three different main phases being assigned to crystalline nanoparticles of $\mathrm{Fe}_{3} \mathrm{O}_{4}$ and $\mathrm{CoFe}_{2} \mathrm{O}_{4}$, as well as an amorphous phase. The morphology of the crystalline grains also reveals another difference, with Co spinel ferrite particles being found to be smaller (5-15 nm) than magnetite particles $(-30 \mathrm{~nm})$. Further investigation were carried out in order to analyse the stoichiometry of the amorphous grains. Quantitative analysis (EDS) of individual nanoparticles carried out in the nanoprobe mode using a spot size of $3 \mathrm{~nm}$ showed Co:Fe compositional variations across the disordered regions. Detailed analysis of these results will be reported later. References

[1] Kaczmarek W. A., Mater. Sci. Forum, 179-81 (1995) 313-20.

[2] Kaczmarek W. A., Proc. 3rd ISMANAM, Rome, 20-24 May 1996, Mater Sci. Forum (in press).

[3] Campbell S. J., Kaczmarek W. A. and Wang G. M., Nanostruct. Mater. 6 (1995) 687-90.

[4] Kaczmarek W. A., Onyszkiewicz I, and Ninham B.W., IEEE Trans. Magn. MAG-30 (1994) 4725-7.

[5] Kunath W., Zemlin F., Weiss K., Ultramicroscopy, 16 (1985) 123-5.

[6] Kaczmarek W. A. and Ninham B.W., IEEE Trans. Magn. MAG-30 (1994) 732-4.

[7] Linderoth S., Jiang J. Z. and Mørup S., Proc. 3rd ISMANAM, Rome, 20-24 May 1996, Mater Sci. Forum (in press). 